\title{
Understanding dynamics of Himalayan glaciers: scope and challenges of remote sensing
}

\author{
S. R. Bajracharya*; S. B. Maharjan, F. Shrestha
}

International Centre for Integrated Mountain Development (ICIMOD), GPO Box 3226 Kathmandu, Nepal, samjwal.bajracharya@icimod.org; sudan.maharjan@icimod.org; finu.shrestha@icimod.org

KEY WORDS: Remote-sensing, Glacier, Decadal change, Geodetic mass balance

\begin{abstract}
:
A remote-sensing based consistent semi-automated glacier mapping methodology with minimum manual intervention has been developed at ICIMOD. Using this methodology the glaciers of Hindu Kush Himalayan region were mapped in 2011 and continuously used for glacier mapping and monitoring in the region. These data were freely available to download from ICIMOD portal and GLIMS database. These comprehensive glacier information are the only data which is being used for research and development projects for countries like Bhutan, Nepal and Pakistan. Recently decadal glacier change from 1980 to 2010 of Nepal and Bhutan were published to understand the glacier change in the Himalaya. The decadal change assessment will be continued in other basins of HKH region to understand the glacier change. Due to rugged terrain, remote access, and logistic hindrance field verification is a challenging task and can be limited only in selected glaciers. Geodetic mass balance study in the selected glaciers like in Yala of Langtang basin and Rikha Samba of Hidden valley are on progress complement to field validation. High resolution images, lack of hydro-meteorological stations near to the glacier and limited competent manpower are another hindrance in the study of glacier change of the HKH region.
\end{abstract}

\section{INTRODUCTION}

The Hindu Kush Himalayan (HKH) region do stand-in as a fresh water tower of south Asia due to reside of high concentration of snow and glaciers at the watershed. The melt of snow and glaciers from these water towers feeding the ten largest river systems in Asia, on which over 1.3 billion peoples are dependent. The Himalayan glaciers had retreated remarkably in the past two decades (Bajracharya et al., 2007, 2014a, b; Fujita et al., 2001) and area loss rates have accelerated in recent decades due to climate change (Bajracharya et al., 2009; Bolch et al., 2012). Although it is still ambiguous which climatic parameter is playing a key role in the glaciers retreat, the current glacier retreat in the Himalayas is due to the combined effect of reduced precipitation and warmer temperature (Ren et al., 2006).

Many of the glaciers in the Himalaya are indeed retreating faster, especially at the lower elevations, indicating a fear in scarcity of water in coming years. Glacier retreat often lead to the formation of glacial lakes, the expansion of existing glacial lakes, and the potential for glacial lake outburst floods (GLOFs). A number of catastrophic GLOFs have already been reported from this region (Bajracharya et al., 2007). The glacial dynamics, the status of glaciers and glaciers change in recent decades should be known in advance from the reliable sources. Landsat images are one of the effective source for obtaining preliminary information about glaciers in relatively unexplored area. The bigger concern in the HKH region however is the lack of long term information on glaciers at the regional level for any kind of credible assessment.

Remote sensing methods are more convenient methods to monitor and measure changes in glaciers. In an effort to assess glacier data around the globe and analyze its change, glacier inventories for most parts of the world have been ingested into the Global Land Ice Measurements from Space (GLIMS) database (Raup et al., 2007) and Randolph Glacier Inventory v:3.0 (Pfeffer et al., 2013) however the mapping source date had a wide temporal range. ICIMOD 2011 (Bajracharya and Shrestha, 2011) and Bolch et al., (2012) (Brahmaputra, Himachal and others new data added) mapped the glaciers of Hindu Kush Himalayan region. The recent revisit of glacier inventory was based on the satellites images of $2005 \pm 3$ years which is an important milestone to understand the glacier dynamics in the region. In addition decadal glacier change from the 1980's to 2010 of Nepal and Bhutan (Bajracharya and others 2014a, b) helped to understand the trend of glacier change in the decades from $\sim 1980$ to 2010 in the eastern Himalaya (Nepal and Bhutan). This paper describes the understanding and behavior of ice dynamics through time and challenges faced in remote sensing technologies for monitoring glaciers.

\section{STUDY AREA AND DATA}

\subsection{Study area}

The HKH region convers the mountain of Hindu Kush, Karakoram and Himalaya that extends about $3600 \mathrm{~km}$ from $15.95^{\circ}$ to $39.31^{\circ} \mathrm{N}$ latitude and $60.85^{\circ}$ to $105.04^{\circ} \mathrm{E}$ longitude, encompassing an area of about 4.2 million square kilometers (Bajracharya et al., 2011) and it expands across all or part of the eight countries including Afghanistan, Bangladesh, Bhutan, China, India, Myanmar, Nepal, and Pakistan (Bajracharya and Shrestha, 2011). There are high concentrations of snow and glaciers

\footnotetext{
${ }^{*}$ Corresponding Author. Tel: +977-1-500-3222; Fax: +977-1-500-3299
} 


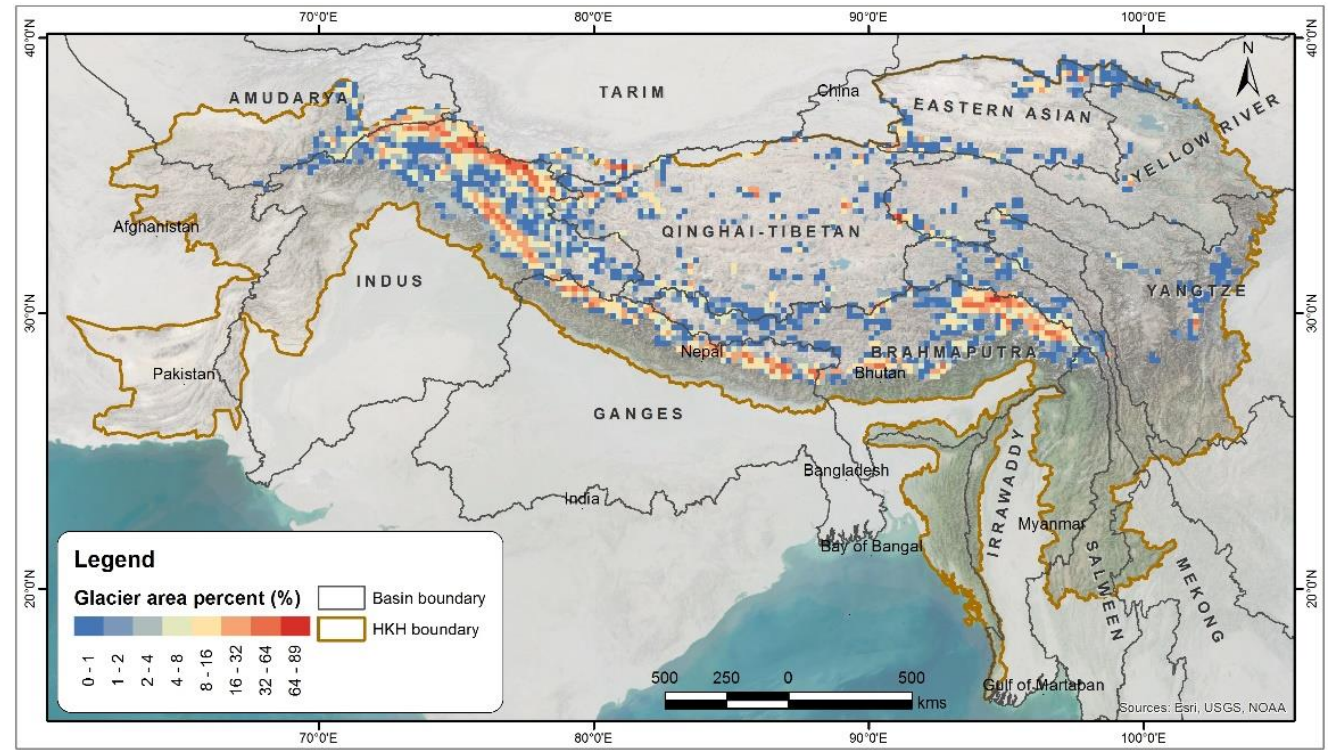

Figure 1. Distribution of glacier area percentage (0.2 degree grid) in the Hindu Kush Himalaya.

in the $\mathrm{HKH}$ region. Meltwater from snow and glaciers feeds the ten largest river systems in Asia: the Amu Darya, Indus, Ganges, Brahmaputra, Irrawaddy, Salween, Mekong, Yangtze, Yellow and Tarim river (Immerzeel et al., 2010; Kaser et al., 2010). This study also focused on three regions for decadal glacier analysis: Shyok valley, a part of Karakoram which covers the eastern part of the Upper Indus basin, Wakhan Corridor located on the northern side of Hindu Kush, Nepal and Bhutan in the eastern Himalaya

\subsection{Data}

About 200 Landsat 7-ETM+ (L1G) scenes (Global Land Cover Facility (GLCF: http://www.landcover.org) used to map the glaciated area of the HKH region. Landsat images were obtained from the United States Geological Survey (USGS). Ninety meter resolution SRTM DEM were used to derive the attribute data for each glacier. The images of Landsat 5-MSS, Landsat 7, and Landsat 7-ETM+ were acquired for the decadal glacier change analysis of Wakhan Corridor in Hindu Kush, Shyok basin in Karakoram and Nepal, Bhutan in Himalayas. We analyzed the glacier changes for 3 periods: 1980-1990, 1990-200 and 2000-2010 for this regions.

\section{METHODS}

The glacier mapping from automated multispectral classification of optical satellite data in combination with a digital elevation model (DEM) is a well-established procedure adopted by many scientists (Frey and Paul, 2012; Bhambri and Bolch, 2009; Bolch et al., 2010; Paul and Kaab, 2005; Paul and Andreassen, 2009; Racoviteanu et al., 2009). These methods satisfactorily delineates the clean ice glacier but thermal bands are found useful for the debris-covered glaciers (Racoviteanu and Williams, 2012; Ranzi et al., 2004). The data used in this study are derived from a semi-automatic methodology with the approach of an object based image classification (OBIC) separately to map clean-ice (CI) and debris-covered (DC) glaciers (Bajracharya and Shrestha, 2011). Using this methodology the glaciers of Hindu Kush Himalayan region were mapped based on the homogeneous source data, short temporal, single method and by small group.

\section{ACCURACY}

The delineated glacier boundaries were affected by various types of obscurities, and maximum offset of the boundary was assigned to each type of obscurity, which could not be greater than half of the image resolution (i.e. $\pm 15 \mathrm{~m}$ in TM and ETM+ and $\pm 40 \mathrm{~m}$ in MSS). Hence, the uncertainties of the glacier area were estimated by variation of each glacier area from glacier polygon (depending on projection parameter) and area calculated on pixel base (depends on image resolution). The pixel based area are calculated as product of total no of pixel bounded by the glacier boundary and the image resolution.

$$
R M S E=\sqrt{\frac{\sum_{i=1}^{n}\left(\mathrm{a}_{i}-\hat{\mathrm{a}}_{i}\right)^{2}}{n}}
$$

Whereas, $\mathrm{a}_{i}=$ Area of glacier from glacier polygon and $\hat{\mathrm{a}}_{i}=$ Area of glacier calculated on pixel base.

The uncertainty of glacier areas in the present study varies from 3.4, 2.5, 2.4 and 2.5 percent for the year's $~ 1980$, 1990, 2000 and 2010 respectively. These mapping uncertainties are within the range of previous estimates of about 3\% (Bolch et al., 2010; Frey et al., 2012; Paul et al., 2002).

\section{RESULTS}

\subsection{Status of glaciers in the Hindu Kush Himalaya}

In total, 54,252 glaciers were mapped within the HKH region with a total area of $60,054 \mathrm{~km}^{2}$ and estimated ice reserves of $6,127 \mathrm{~km}^{3}$. This reveals that only $1.4 \%$ of the $\mathrm{HKH}$ region is glaciated; the total ice reserves are roughly equal to three times the annual precipitation (Bookhagen and Burbank, 2006; Immerzeel et al., 2010) . There is a 


\begin{tabular}{|l|r|r|r|r|r|r|}
\hline \multirow{2}{*}{ Basins } & \multirow{2}{*}{$\begin{array}{c}\text { Number of } \\
\text { glaciers }\end{array}$} & \multicolumn{2}{c|}{ Area of glaciers $\left(\mathrm{km}^{2}\right)$} & \multirow{2}{*}{$\begin{array}{c}\text { Estimated ice } \\
\text { reserves }\left(\mathrm{km}^{3}\right)\end{array}$} & \multicolumn{2}{c|}{ Elevation (masl) } \\
& 3,277 & Total & Average & Highest & \multicolumn{1}{c|}{ Lowest } \\
\hline Amu Darya & 18,495 & 21,193 & 0.78 & 162.6 & 7,213 & 3,131 \\
\hline Indus & 7,963 & 9,012 & 1.13 & 2696.1 & 8,566 & 2,409 \\
\hline Ganges & 11,497 & 14,020 & 1.22 & 793.5 & 8,806 & 3,273 \\
\hline Brahmaputra & 133 & 35 & 0.27 & 1302.6 & 8,331 & 2,435 \\
\hline Irrawaddy & 2,113 & 1,352 & 0.64 & 1.3 & 4,256 & 5,695 \\
\hline Salween & 482 & 235 & 0.49 & 87.7 & 6,471 & 3,786 \\
\hline Mekong & 1,661 & 1,660 & 1 & 10.7 & 6,361 & 2,891 \\
\hline Yangtze & 189 & 137 & 0.73 & 121.4 & 6,270 & 2,972 \\
\hline Yellow & 1,091 & 2,310 & 2.12 & 9.2 & 5,710 & 4,151 \\
\hline Tarim & 7,351 & 7,535 & 1.02 & 378.6 & 6,462 & 3,940 \\
\hline Interior & 54,252 & 60,054 & 1.11 & 563.1 & 6,609 & 3,994 \\
\hline HKH & & & 6126.9 & 8,806 & 2,409 \\
\hline
\end{tabular}

Table 1. Status of glaciers of HKH region based on the landsat images of $2005 \pm 3$ years

large variation between river basins hence the largest contribution of total glacier areas are found in the Indus, Brahmaputra, and Ganges basins respectively (Table 1).

The largest glaciated area concentration in the HKH was found at elevations between 5,000 and 6,000 masl i.e. the proportion of glacier area located at these elevations was $60 \%$ of the total area, though the glaciers were found highest at elevation 8,806 masl in the Ganga basin and lowest at 2,409 masl in the Indus basin. The glaciers below 5,700 masl are noticed to be sensitive to changing climate unless covered by thick debris (Bajracharya et al., 2014b).

\subsection{Decadal glacier change from 1980 's to 2010 in selected basins of the HKH region}

Over the 30 years from the 1980's to 2010, the glaciers of the Wakhan corridor, Hindu Kush are relatively stable however some showed a slight reduction in glacier area, which was most prominent at the glacier tongues (Bajracharya et al., 2014). The glaciers in the Shyok basin of Karakoram showed shrinkage during 1980s while in later periods remained static or advanced in glacier tongue however observation showed some losses in glacier area at steeper slope.

The glaciers in the Himalaya are retreating faster than those in the Hindu Kush and Karakoram, with losses of area of 5 to $55 \%$ in 30 years. The Himalayan basins like Imja valley in Nepal and Lunana region in Bhutan showed similar trends, with the highest losses of glacier area observed in the periods 1980-90 and 2000-2010 respectively. The decadal glacier change from 1980 to 2010 shows $24 \%$ and $23 \%$ glacier area loss in Nepal and Bhutan respectively (Bajracharya et al. 2014a,b)(Table 2). Even high loss of about $38 \%$ were reported on glaciers $<1 \mathrm{~km}^{2}$ in Himachal Himalaya from 1962 to 2004 (Kulkarni et al., 2007).

\section{DISCUSSION}

We found notable differences and change in the glacier area in Hindu Kush, Karakoram and Himalaya regions. Comparison of glaciers area showed that retreat rate was remarkably higher in the Himalayan glaciers than those in the Hindu Kush and Karakoram, with losses of area by 5 to $55 \%$ over 30 years. On other hand, glaciers in Karakoram basin in recent decade shows the evidence of slight but significant gain in glacier mass in the terminus region. Previous studies also support the fact in advancement of glacier area in Karakoram basin (Gardelle et al., 2012, Bhambri et al., 2013). In Hindu Kush, all four decades data indicate that glaciers are losing mass. Recent studies also indicated that most of the glaciers in Hindu Kush have retreated and lost mass between 1976 and 2003 (Haritashya et al., 2009) and between 1976 and 2007 (Sarikaya et al., 2012).

A total of 54,252 individual glaciers were identified with an overall area of $60,054 \mathrm{~km}^{2}$ and an estimated $6,127 \mathrm{~km}^{3}$ of ice reserves. The distribution of glaciers are found at 8800 to 2400 masl in the HKH region, but over $60 \%$ of the total glacier area is located at elevation 5000-6000 masl (Figure 2). The glaciated regions are mostly at the remote area with rugged terrain and lack of logistic facilities and harsh climatic condition. Field mapping of glaciers are possible only in the limited glaciers with lot of resources in terms of time and cost. In the context of vast glacier area and rapid melting of glaciers the remote sensing tools and techniques have proved to be the most appropriate for mapping and monitoring of glaciers in the HKH region. Moreover, inventory of four decades (1980 to 2010) glacier data and its change analysis in some basins of $\mathrm{HKH}$ region has become only possible with the advent of remote sensing technology.

A remote-sensing based consistent semi-automated glacier mapping methodology with minimum manual intervention has been developed at ICIMOD. Using this methodology the glaciers of Hindu Kush Himalayan region were mapped based on the homogeneous source data, short temporal, single method and by small group in 2011. These glacier data were the most reliable for the glacier monitoring. The glacier outline were delineated from low snow and cloud-free images. However, the freely downloadable images rarely meet the ideal requirements, hence for decadal analysis images were used nearby years rather than the exact required year. The suitability of a particular images depends on the presence/absence of seasonal snow, cloud cover and the date of acquisition. The images for $\sim 1980$ had a smaller choice and somewhat more snow cover than those from the other years. The presence of snow, and the resultant loss in the clarity of glacier boundaries, have contributed somewhat increase in glacier area especially for $\sim 1980$ to 1990. 


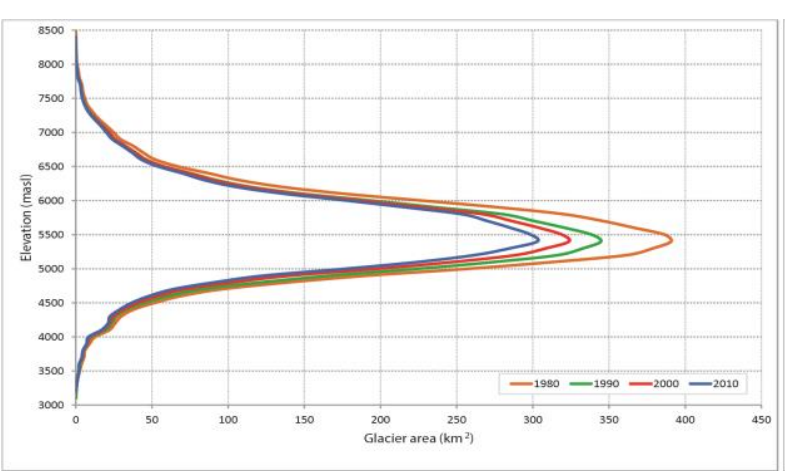

a) Nepal

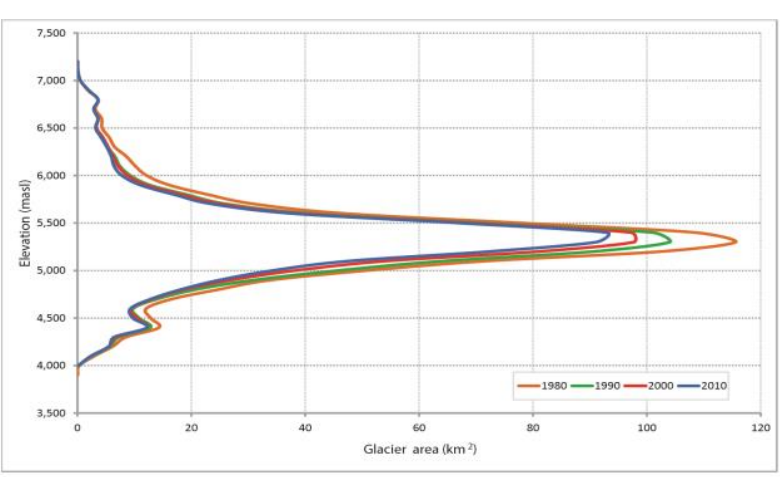

b) Bhutan

Figure 2. The $100 \mathrm{~m}$ area-elevation distribution of glaciers of Nepal and Bhutan in 2010

\subsection{Debris cover}

The most difficult part in remote sensing is to map the debris cover glaciers. However the debris cover glacier mapped by using manual or automatic from multispectral and/or thermal bands still not verified in the field. Difficult to interpret the debris covered glacier, whether under the debris are ice mass or not even ice are dead ice or dynamic. The decadal glacier change mapping has shown increase of debris-covered glacier from 1990 to 2000. The increased debris-covered glacier area during four periods also confirmed the melting of clean-ice glaciers. However the debris-covered glaciers with lake at snout showed faster recession due to the expansion of lakes or formation of supraglacial lakes, best example reflected in the Lunana region of Bhutan and Imja Lake of Nepal.

A thick debris layer has a strong insulating effect and subdebris melt rates can be a factor of 5 to 10 lower than for CI glaciers (Hagg et al., 2008; Mihalcea et al., 2006). A total of $32,000 \mathrm{~km}^{2}$ of the glacier area was categorized as either DC or CI (glaciers within China were not differentiated). Of this, $9.7 \%$ overall was classified as DC, and $9.3 \%, 11.1 \%$, and $12.6 \%$ of the differentiated area in the Indus, Brahmaputra, and Ganges basins, respectively. DC glaciers are mostly found at the frontal part of valley glaciers and have an average slope of $12^{\circ}$; much less steep than CI glaciers, which have an average slope of $25^{\circ}$ (Bajracharya and Shrestha, 2011; Bolch et al., 2012).

\subsection{Elevation}

The distribution of area altitude have provided insight into glacier interaction within different elevation zone. The glaciers that extend to low elevations showed distinct change in glacier size. Especially debris-covered glaciers with lake which showed rapid melting rates in ice mass indicating the expansion and formation of lakes. Similarly the glaciers near median elevation shrank noticeably with decadal scale revealing the melting in surface area. However the glaciers at the higher elevation doesn't change as significantly as those at lower elevation.

The glaciers below 5800 masl to Nepal and 5400 masl to Bhutan are particularly sensitive to climate change unless they are covered by thick debris (Figure 2) (Bajracharya et al., 2014a). The threshold value to HKH region is 5700 masl, the Indus, Ganges, and Brahmaputra basins have $79 \%, 60 \%$, and $77 \%$ of their total glacier area, respectively, below this critical elevation. Clean ice glaciers at low altitude and small glaciers are the most sensitive glaciers to climate change in the HKH region.

\subsection{Volume estimates}

Estimations of ice volumes in the Himalayas are highly uncertain and range from $\sim 2300 \mathrm{~km}^{3}$ to $\sim 6500 \mathrm{~km}^{3}$ (Bolch et al., 2012).Various approaches have been proposed to estimate glacier volumes for the HKH region, such as volume-area (V-A) relations (e.g., Chen and Ohmura, 1990; Bahr et al., 1997), slope-dependent ice thickness estimations (Haeberli and Hoelzle, 1995), and more recently, a variety of spatially distributed ice-thickness models (e.g., Clarke et al., 2009; Farinotti et al., 2009; Linsbauer et al., 2009; Huss and Farinotti, 2012; Li et al., 2012; McNabb et al., 2012; Van Pelt et al., 2013). The total volume estimates from area-related relations are larger than those from other approaches (Frey et al., 2013). Available volume estimates for the $\mathrm{HKH}$ region indicate large differences even due to the inconsistent delineations of glaciers. The estimation of volume is depending upon the approaches and glacier outline.

\begin{tabular}{|l|r|r|r|r|r|r|r|r|}
\hline \multirow{3}{*}{ Elevation(masl) } & \multicolumn{9}{|c|}{ Year } & \multicolumn{5}{|c|}{ Decade } \\
\cline { 2 - 8 } & 1980 & 1990 & 2000 & 2010 & $90-80$ & $00-90$ & $10--00$ & $10--80$ \\
\cline { 2 - 8 } & \multicolumn{9}{|c|}{ Glacier area $\left(\mathrm{km}^{2}\right)$} \\
\hline Nepal & 3514.4 & 3064.3 & 2821.3 & 2575.6 & -450.1 & -243 & -245.7 & -938.8 \\
\hline$<5800$ & 1653.9 & 1442 & 1389.6 & 1326.8 & -211.9 & -52.4 & -62.8 & -327.1 \\
\hline$\geq 5800$ & 5168.3 & 4506.3 & 4210.9 & 3902.4 & -662 & -295.4 & -308.5 & -1265.9 \\
\hline Total & \multicolumn{9}{|c|}{} \\
\hline Bhutan & 659.6 & 592.5 & 544.5 & 507 & -67.1 & -48 & -37.5 & -152.6 \\
\hline$\leq 5600$ & 178 & 148 & 143.5 & 134.8 & -30 & -4.5 & -8.7 & -43.2 \\
\hline$>5600$ & 837.6 & 740.7 & 688.2 & 642.1 & -96.9 & -52.5 & -46.1 & -195.5 \\
\hline Total &
\end{tabular}

Table 2. Decadal glacier area change at below and above 5800 masl in Nepal and 5600 masl in Bhutan from 1980 to 2010 


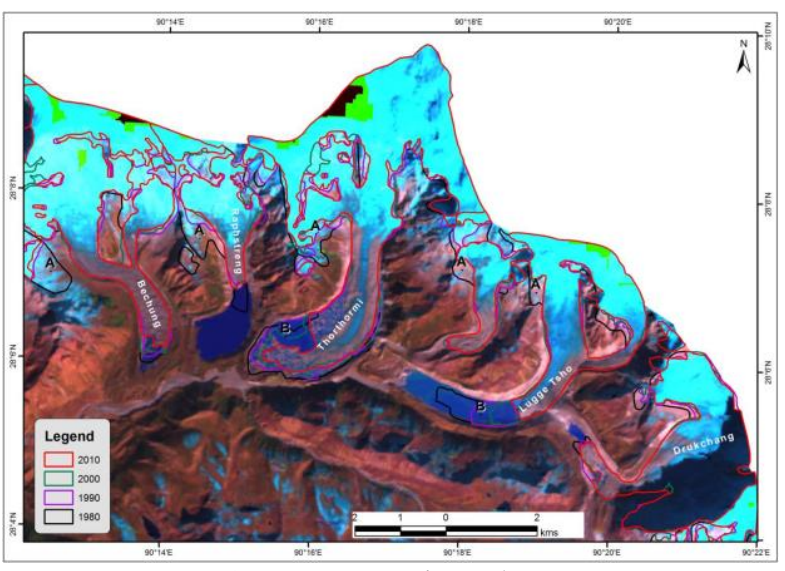

a) Lunana region, Bhutan

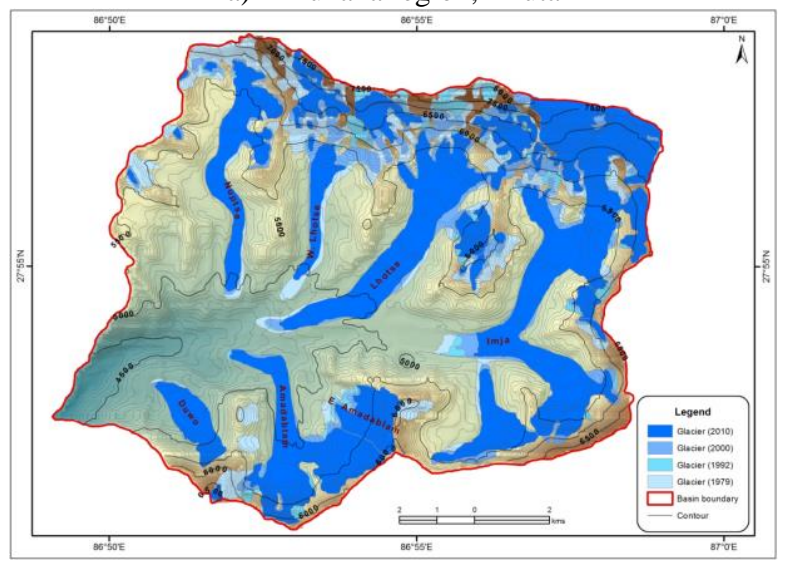

b) Imja valley, Nepal

Figure 3. Decadal outline of glaciera from 1980s, 1990, 2000 and 2010. Glacier retreated mostly from the elevation less than 5800 at the steeper slope and in the lake area.

\subsection{Geodetic mass balance}

Estimation of changes in the total mass of a glacier by geodetic requires the difference in elevation between two DEMs. This difference is averaged over the entire glacier surface to obtain the mean change in height and thus volume. This method has been applied in some parts of $\mathrm{HKH}$ region based on historical topography maps and DEMs derived from SPOT imagery (Berthier et al., 2007; Gardelle et al., 2013), declassified Hexagon stereo imagery (Maurer 2013), Cartosat-1, ASTER ((Pieczonka et. al., 2011). Recent study reported that there was a slight mass gain or balanced mass budget of glaciers in the central Karakoram while moderate mass losses in the eastern and central Himalaya (Gardelle et al., 2013; Kaab et al., 2012). There are also some constraints and uncertainties associated with elevation data that arise mainly from orientation errors, surface type properties uneven climatic condition, poor contrast in snow covered and shadow areas and the inaccurate identification of corresponding features in the stereo models..

\section{CHALLENGES}

Delineation of glaciers from full atomization are still a challenging tasks for researcher. Even standard algorithm fails to provide meaningful comparisons between multitemporal analyses of the same region. Multispectral techniques show somehow promising result for delineating the boundaries of clean-ice glaciers (Paul et al., 2002) however debris covered glaciers require the use of digital elevation model (DEM) or topographic information for accurate delineation. Many of remotely sensed data are freely available or at low cost, however, the freely downloadable images rarely meet the ideal requirements due to snow and cloud cover (narrow window) and short season. Acquiring cloud-free satellite imagery is still challenging. DEMs derived from SPOT5, ASTER, CORONA or ALOS PRISM can be used in mass balance studies however these images are very expensive and using them requires specialized skill and tools. The Landsat 7-ETM+ images after 2003 June onward suffer from a scan line corrector (SLC) failure. The total loss of image data has been estimated to be approximately 22 percent over any given scene. In addition, the resolution of the Landsat multispectral scanner (MSS) image may not be adequate to identify smaller glaciers.

Assumption of constant snow and ice thickness and density in the glacier as there is no any research on snow thickness and density of ice in the Himalayan. Ground penetrating radar (GPR) is good modern technology to analysis the snow and ice thickness and density in the glacier which is also not in practice in the Himalayan terrain. There will be high uncertainties in remote sensing generated data unless the data were rectified from the field validation. Collecting ground controls points in the remote, rugged and steep terrain of the Himalaya is very difficult, time consuming and expensive.

Lidar is another promising remote sensing tool for measuring glacier variations and landscape modifications as it has an ability to acquire high resolution 3D surface data (Avian et al., 2007). Nevertheless, due to costly instrument and requirement of specialized skill and tools for data processing, it has not been applied in the Himalayas. But, both - airborne (ALS) and Terrestrial (TLS) Lidar can be found applied in the Alps for glaciological applications at early 2000's (Avian et al., 2007; Geist et al., 2003; Bauer et al., 2003).

\section{CONCLUSIONS}

The glacier area is rapidly changing in the Himalayas. In recent decade, remote sensing technology has made tremendous scope in understanding and mapping of ice dynamics. For most part, where field measurements of glaciers are often not a viable option, the use of remote sensing techniques ensure to generate consistent data at the global scale. It can be used for inventory, mapping and long term monitoring to make a more complete assessment in terms of water resources, hazard prediction and detection. The Landsat data provides an ideal tool to understand the status and changes on glaciers at least for last 30 years in the HKH region. For precise glacier variation and landscape modification high resolution images with $3 \mathrm{~d}$ capability and modern technology should be used at least at the important basins for availability of water resources, glacial hazard, and climate change impact study. 


\section{ACKNOWLEDGEMENTS}

We are grateful to MSR Murthy, Arun Bhakta Shrestha, and Pradeep Kumar Mool for their consistent inspiration, and support to undertake the research activities. This study was partly supported by HIMALA and SERVIR Himalaya of NASA and USAID. Landsat data are courtesy of NASA and USGS, and the SRTM elevation model version is courtesy of NASA JPL and was further processed by CGIAR. The glacier database was generated with the support from the Cryosphere Monitoring Project of the Swedish International Development Cooperation Agency (SIDA) and the Norwegian Ministry of Foreign Affairs. We are grateful to them all.

\section{REFERENCES}

Avian, M., Gerhard, K.L., Andreas, K.P., Arnold, B., 2007. Variations of Pasterze Glacier (Austria) Between 1994 and 2006 - Combination of Different Data Sets for Spatial Analysis, 9th International Symposium on High Mountain Remote Sensing Cartography.

Bajracharya, S.R., Maharjan, S.B., Shrestha, F., 2014a. The status and decadal change of glaciers in Bhutan from 1980 's to 2010 based on the satellite data. Ann. Glaciol., 55(66), pp. 159-166. doi: 10.3189/2014AoG66A125.

Bajracharya, S.R., Maharjan, S.B., Shrestha, F., Bajracharya, O.R., Baidya, S., 2014b. Glacier status in Nepal and decadal change from 1980 to 2010 based on Landsat data. Kathmandu: ICIMOD.

Bajracharya, S.R., Shrestha, B.R., (Eds) 2011. The status of glaciers in the Hindu Kush-Himalayan region, Kathmandu, ICIMOD.

Bajracharya, S.R., Mool, P., 2009. Glaciers, glacial lakes and glacial lake outburst floods in the Mount Everest region, Nepal. Ann. Glaciol., 50(53), pp. 81-86.

Bajracharya, S.R., Mool, P., Shrestha, B.R., 2007. Impact of climate change on Himalayan glaciers and glacial lakes : case studies on GLOF and associated hazards in Nepal and Bhutan. Kathmandu, ICIMOD and UNEP.

Bauer, A., Paar, G., Kaufmann, V., 2003: Terrestrial laser scanning for rock glacier monitoring. In: Phillips, M., Springman, S.M., and Arenson, L.U. (Eds.) Proceedings of the 8th International Permafrost Conference, Zurich, $55-60$.

Berthier E., Arnaud Y., Rajesh K., Sarfaraz A., Wagnon P., Chevallier P., Remote sensing estimates of glacier mass balances in the Himachal Pradesh (Western Himalaya, India). Remote Sens. Environ., 108(3), pp. 327338. doi:10.1016/j.rse.2006.11.017, 2007

Bhambri, R., Bolch, T., Kawishwar, P., Dobhal, D.P., Srivastava, D., Pratap, B., 2013. Heterogeneity in glacier response in the upper Shyok valley, northeast Karakoram. The Cryosphere, 7, pp. 1385-1398. doi:10.5194/tc-7-1385

Bhambri, R., Bolch, T., 2009. Glacier mapping: a review with special reference to the Indian Himalayas. Progress in Phys. Geogr., 33(5), pp. 672-704.
Bahr, D., Meier, M., Peckham, S., 1997. The physical basis of volume-area scaling. J. Geophy. Res: Solid Earth., 102, pp. 20335-20362.

Bolch, T., Kulkarni, A., Kääb, A., Huggel, C., Paul, F., Cogley, J.G., Frey, H., Kargel, J.S., Fujita, K., Scheel, M., Bajracharya, S., Stoffel, M., 2012. The state and fate of Himalayan glaciers. Science, 336(6079), pp. 310-314.

Bolch, T., Menounos, B., Wheate, R., 2010. Landsatbased inventory of glaciers in western Canada, 19852005. Remote Sens. Environ., 114(1), pp. 127-137.

Bookhagen, B., Burbank, D.W., 2006. Topography, relief, and TRMM-derived rainfall variations along the Himalaya. Geophys. Res. Lett., 33, pp. 1-5.

Chen, J., Ohmura, A., 1990. Estimation of Alpine glacier water resources and their change since 20 the 1870s. In Lang, H., Musy, A., (Eds), Hydrology in Mountain Regions. I-Hydrological Measurements; the Water Cycle, Proceedings of two Lausanne Symposia, August 1990, 193, pp. 127-135. Wallingford, UK: IAHS Publications.

Clarke, G.K.C., Berthier, E., Schoof, C.G., Jarosch, A.H., 2009. Neural networks applied to estimating subglacial topography and glacier volume. J. Clim., 22, pp. 21462160 .

Frey, H., Machguth, H., Huss, M., Huggel, C., Bajracharya, S., Bolch, T., Kulkarni, A., Linsbauer, A., Salzmann, N., Stoffel, M., 2013. Ice Volume estimates for the Himalaya-Karakoram region:evaluating different methods. The Cryosphere, 7(5), pp. 4813-4854. doi:10.519/tcd-7-4813-2013.

Frey, H., Paul, F., 2012. On the suitability of the SRTM DEM and ASTER GDEM for the compilation of topographic parameters in glacier inventories. Int. J Appl Earth Obs. 18, pp. 480-490.

Gardelle, J., Berthier, E., Arnaud, Y., \& Kääb, A., 2013. Region-wide glacier mass balances over the PamirKarakoram-Himalaya during 1999-2011. The Cryosphere, 7, pp. 1263-1286.doi:10.5194/tc-7-12632013.

Gardelle, J., Berthier, E., Arnaud, Y., 2012. Slight mass gain of Karakoram glaciers in the early 21 st century, Nat. Geosci., 5, pp. 322-325, doi: 10.1038/ ngeo1450.

Geist T., Lutz, E., Stötter, J., 2003. Airborne Laser Scanning Technology and its Potential for Applications in Glaciology. In: Proceedings. ISPRS Workshop on 3-D Reconstruction from Airborne Laserscanner and INSAR Data, Dresden.

Hagg, W., Mayer, C., Lambrecht, A., Helm, A. 2008. SubDebris Melt Rates on Southern Inylchek Glacier, Central Tian Shan. Geografiska Annaler. Series A., 90(1), 55-63. doi:10.1111/j.1468-0459.2008.00333x.

Haeberli, W., Hoelzle, M., 1995. Application of inventory data for estimating characteristics of and regional climatechange effects on mountain glaciers: A pilot study with the European Alps. Ann. Glaciol., 21, pp. 206-212. 
Huss, M., Farinotti, D., 2012. Distributed ice thickness and volume of all glaciers around the globe. J. Geophy. Res: Earth Surf., 117(F04). doi:10.1029/2012JF002523

Haritashya, U. K., Bishop, M. P., Shroder, J. F., Bush, A. B. G., Bulley, H. N. N., 2009. "SpaceBased Assessment of Glacier Fluctuations in the Wakhan Pamir, Afghanistan." Clim. Chang., 94, pp. 5-18.

Immerzel, W. W., Van Beek, L. P. H., Bierkens, M. F. P., 2010. Climate change will affect the Asian water towers. Science, 328(5984), pp. 1382-5. doi:10.1126/science.1183188.

Kääb, A., Berthier, E., Nuth, C., Gardelle, J., Arnaud, Y., 2012.Contrasting patterns of early twenty-first-century glacier mass change in the Himalayas. Nature, 488(7412), pp. 495-498.

Kaser, G., Großhauser, M., Marzeion, B., 2010. Contribution potential of glaciers to water availability in different climate regimes. In: Proceedings of the National Academy of Sciences of the United States of America, 15. doi:10.1073/pnas.1008162107

Kulkarni, A.V., Bahuguna, I.M., Rathore, B.P., Singh, S.K., Randhawa, S.S., Sood, R.K., Dhar, S., 2007. Glacial retreat in Himalaya using Indian Remote Sensing satellite data. Curr. Sci., 92(1), pp. 69-74.

Li, H., Ng, F., Li, Z., Qin, D., Cheng, G., 2012. An extended "perfect-plasticity" method for estimating ice thickness along the flow line of mountain glaciers. $J$. Geophy. Res., 117(F1). doi:10.1029/2011JF002104.

Linsbauer, A., Paul, F., Hoelzle, M., Frey, H., Haeberli, W., 2009. The Swiss Alps without glaciers- a GIS-based modelling approach for reconstruction of glacier beds. In: Proceedings of the geomorphometry, Zurich, pp. 243-247

Maurer, J., Rupper, S., 2013. Evaluatin of Hexagon Imagery for Regional Mass Balance Study in the Bhutan Himalayas. Utah Space Grant Consortium.

Mihalcea, C., Mayer, C., Diolaiuti, G., Lambrecht, A., Smiraglia, C., Tartari, G., 2006. Ice ablation and meteorological conditions on the debris-covered area of Baltoro glacier, Karakoram, Pakistan. Ann. Glaciol., 43(1), pp. 292-300.

McNabb, R. W., Hock, R., O’Neel, S., Rasmussen, L. A., Ahn, Y., Braun, M., Conway, H., Herreid, S., Joughion, I., Pfeffer, W. T., Smith, B. E., Truffer, M., 2012. Using surface velocities to calculate ice thickness and bed topography: a case study at Columbia Glacier, Alaska, USA, J. Glaciol., 58, pp. 1151-1164. doi:10.3189/2012JoG11J249.

Paul, F., Liss, M.A., 2009. A new glacier inventory for the Svartisen region, Norway, from Landsat ETM+ data:
Challenges and change assessment. J. Glaciol. 55(192), pp. 607-618.

Paul, F., Kaab, A., 2005. Perspectives on the production of a glacier inventory from multispectral satellite data in Arctic Canada: Cumberland Peninsula, Baffin Island. Ann. Glacio., 42, pp. 59-66.

Paul, F., Kaab, A., Maisch, M., Kellenberger, T., Haeberli, W., 2002. The new remote-sensing-derived Swiss glacier inventory. I. Methods. Ann. Glacio., 34, pp. 355-361.

Pfeffer, W. T., 18 others and Randolph consortium., 2013. The Randolph glacier inventory [v3.0]: a globally complete inventory of glaciers. Colorado, USA (http://www.glims.org/RGI/randolph.html)

Pieczonka, T., Bolch, T., Buchroithner, M.F., 2011. Generation and evaluation of multi-temporal digital terrain model of the Mt. Everest area from different optical sensors. ISPRS J. Photogramm. Remote Sens., 66, pp. 927-940. doi:10.1016/j.isprsiprs.2011.07.003.

Racoviteanu, A., William, M.W., 2012. Decision tree and texture analysis for mapping debris-covered glaciers in the Kangchenjunga area, Eastern Himalaya. Remote Sens., 4(10), pp. 3078-3109, doi:10.3390/rs4103078.

Racoviteanu, A.E., Raup, B., Khalsa, S.J.S., Armstrong, R., Paul, F., 2009. Challenges and recommendations in mapping of glacier parameters from space: Results of the 2008 global land ice measurements from space (GLIMS) workshop, Boulder, Colorado, USA. Ann. Glaciol., 50(53), pp. 53-69.

Ranzi, R., Grossi, R., Iacovelli, 1., Taschner, T., 2004. Use of multispectral ASTER images for mapping debriscovered glaciers within the GLIMS Project. IEEE International Geoscience and Remote Sensing Symposium 2, pp. 1144-1147

Raup, B., Racoviteanu, A., Khalsa, S., Helm, C., Armstrong, R. Arnaud, Y., 2007. The GLIMS Geospatial Glacier Database: A new tool for studying glacier change. Glob. Planet. Chang., 56, pp. 101-110.

Ren, J., Jing, Z., Pu, J., Qin, X., 2006. Glacier variations and climate change in the central Himalaya over the past few decades. Ann. Glacio., 43(1), pp. 218-222.

Sarikaya, M. A., Bishop, M. P., Shroder, J. F., Olsenholler J. A., 2012. "Space-Based Observations of Eastern Hindu Kush Glaciers Between 1976 and 2007, Afghanistan and Pakistan." Remote Sens. Lett. 3 (1), pp. 77-84.

Van Pelt, W.J.J., Oerlemans, J., Rejimer, C.H., Pettersson, R., Pohjola, V.A., Isaksson, E., Divine, D., 2013. An iterative inverse method to estimate basal topography and initialize ice flow models. The Cryosphere, 7, pp. 9871006. doi:10.5194/tc-7-987-2013 